\title{
Effects of serum starvation and re-cloning on the efficiency of nuclear transfer using bovine fetal fibroblasts
}

\author{
V. Zakhartchenko ${ }^{1}$, G. Durcova-Hills ${ }^{1}$, M. Stojkovic ${ }^{2}$, W. Schernthaner ${ }^{1}$, K. Prelle ${ }^{2}$, R. Steinborn ${ }^{3}$, \\ M. Müller ${ }^{3}$, G. Brem ${ }^{3}$ and E. Wolf ${ }^{1,2^{*}}$ \\ ${ }^{1}$ Bavarian Research Centre for Biology of Reproduction (BFZF); ${ }^{2}$ Department of Molecular Animal Breeding and Genetics, Ludwig- \\ Maximilian University, D-85764 Oberschleissheim, Germany; and 'Institute of Animal Breeding and Genetics, Vienna, Austria
}

\begin{abstract}
The developmental potential of bovine fetal fibroblasts was evaluated using nuclear transfer. Fibroblasts from a 37-day-old fetus were fused to enucleated oocytes before activation. Nuclei of starved (cultured for 8 days in medium containing $0.5 \%$ serum) fibroblasts supported the development of reconstructed embryos to the blastocyst stage significantly better than those of non-starved fibroblasts $(39 \%$ versus $20 \% ; P<0.05)$. When nuclear transfer morulae derived from starved or non-starved fibroblasts were used for re-cloning, the proportion of blastocysts (52 and 55\%, respectively) obtained with these embryonic nuclei was significantly higher than it was with fibroblast nuclei used in the first round of nuclear transfer $(P<0.05$ and $P<0.001$, respectively). After transfer of blastocysts derived from non-starved and starved fibroblasts, respectively, $33 \%(1 / 3)$ and $78 \%(7 / 9)$ of recipients were pregnant on day 30 as assessed by ultrasonography. On day 90 , the corresponding pregnancy rates were $33 \%(1 / 3)$ and $63 \%(5 / 8)$. Two live male twin calves, derived from non-starved fibroblasts, were delivered by Caesarean section at day 281 of gestation. This study demonstrates a positive effect of serum starvation on the efficiency of nuclear transfer using bovine fetal fibroblasts. The efficiency of nuclear transfer could be further increased by recloning.
\end{abstract}

\section{Introduction}

Nuclear transfer using embryonic cells as donors of genetic material is an important method both for producing cloned animals and for research purposes. However, this approach has little value for the introduction of new genes or genetic modifications. The ability to produce cloned offspring by nuclear transfer from a cell population that can be maintained in culture or under other appropriate conditions offers numerous advantages in the fields of research, agriculture and biotechnology. An established cell line provides the opportunity to modify the genomes and select the required cell populations before embryo reconstruction (for review, see Wolf et al., 1998).

Although embryonic stem (ES) cell technology is established in mice and used for a plethora of research applications, so far no cell lines are available from livestock species that meet all characteristics of mouse ES cells, that is, germ-line transmission after generation of chimaeric animals (Stice and Strelchenko, 1996). However, bovine inner cell mass cells in primary culture - a cell lineage that has the potential to be maintained as ES cells - supported the birth of live offspring when used as donors for nuclear transfer (Sims

*Correspondence.

Received 18 June 1998. and First, 1993; Itoh et al., 1998). In sheep, Campbell et al. (1996a) and Wells et al. (1997) were able to produce live cloned offspring from embryonic disc cells that had been maintained in culture for up to 13 and up to 9 passages, respectively.

A number of attempts have been made to use cells from later developmental stages for nuclear transfer. Live sheep have been produced by nuclear transfer using fetal fibroblasts (Schnieke et al., 1997; Wilmut et al., 1997) or adult mammary gland cells (Wilmut et al., 1997). In these studies, it has been proposed that successful reprogramming of the donor chromatin from differentiated cells may relate to the serum starvation of donor cells and the concomitant arrest in G0 of the cell cycle. Similarly, pregnancies have been reported in cattle after transfer to recipients of cloned embryos derived from serum-starved fetal fibroblasts (Wells et al., 1998) or muscle and skin fibroblast-like cells (Vignon et al., 1998). From the latter study, the birth of a live calf has been announced (see Butler, 1998). However, live calves have also been born after nuclear transfer using non-starved fetal fibroblasts (Cibelli et al., 1998).

Since the studies mentioned above used only cells either with or without serum starvation, the aim of the present study was to evaluate the effect of serum starvation on the efficiency of nuclear transfer using bovine fetal fibroblasts. In addition, some of these nuclear transfer embryos were used 
for re-cloning to study the consequences of a second round of nuclear reprogramming on embryonic development.

\section{Materials and Methods}

\section{Karyoplasts}

Fetal fibroblasts were obtained from a $2.0 \mathrm{~cm}$ bovine fetus (37-day-old) of a 5-year-old German Simmental cow. The sex of the fetus was male as determined by PCR (Carvalho et al., 1996). The isolated fetus was washed three times in $\mathrm{Ca}^{2+}$ and $\mathrm{Mg}^{2+}$-free PBS. The head and all internal organs were removed and the remnant tissues were cut into small pieces and dispersed by exposure to $0.1 \%(\mathrm{w} / \mathrm{v})$ trypsin (Gibco, Grand Island, NY). The cell suspension was then transferred into $10 \mathrm{~cm}$ culture dishes containing Dulbecco's modified Eagle's medium (Gibco) supplemented with $10 \%$ (v/v) fetal calf serum (Biochrom, Berlin), 2 mmol L-glutamine $\mathrm{l}^{-1}, 10^{-4}$ mol 2-mercaptoethanol $1^{-1}, 2 \mathrm{mmol}$ non-essential amino acids $\mathrm{l}^{-1}$ (Sigma, St Louis, MO), $100 \mathrm{iu}$ penicillin $\mathrm{ml}^{-1}$ and $100 \mu \mathrm{g}$ streptomycin $\mathrm{ml}^{-1}$ (passage 0 ). The cells were cultured until sub-confluence (usually $2-3$ days) at $37^{\circ} \mathrm{C}$ in $5 \% \mathrm{CO}_{2}$ in air and then frozen in $10 \%(\mathrm{v} / \mathrm{v})$ dimethyl sulfoxide (Sigma) in culture medium and stored in liquid nitrogen. For experiments, the cells were thawed and cultured for up to four passages. Cells were used for nuclear transfer directly or after serum starvation (Campbell et al., 1996a). The nonstarved cells cultured until sub-confluence were used for nuclear transfer 2-3 days after passage. The culture medium was removed 1 day after passage to start serum starvation, the cells were washed three times with PBS and fresh medium containing $0.5 \%(\mathrm{v} / \mathrm{v})$ FCS was added. The cells were then cultured for a further 8 days before use for nuclear transfer.

\section{Immunofluorescence microscopy}

Immunofluorescence detection of proliferating cell nuclear antigen (PCNA), which is an indicator of active DNA replication, was performed using non-starved or starved fibroblasts to evaluate whether the serum starvation altered the phase of the cell cycle of the donor cells. DNA replication (S phase) was also monitored using the thymidine analogue, 5-bromo-2'-deoxyuridine (BrdU).

Non-starved or starved cells were grown on gelatinized coverslips $(18 \mathrm{~mm} \times 18 \mathrm{~mm})$ for 2 or 8 days and then washed three times with PBS. Methanol fixation was carried out at $-20^{\circ} \mathrm{C}$ for $6 \mathrm{~min}$ to recognize only the insoluble form of PCNA which is associated with the site of ongoing DNA synthesis during S-phase. Coverslips containing fixed cells were washed three times with PBS and covered with $50 \mu \mathrm{l}$ fluorescein isothiocyanate (FITC)-conjugated mouse antiPCNA antibody (1:50 in PBS containing 1\% (w/v) BSA; (Dako, Hamburg)). After incubation for $1 \mathrm{~h}$ at $37^{\circ} \mathrm{C}$ in a humidified atmosphere, the coverslips were washed three times in PBS and once in distilled water. Alternatively, cells were incubated with $10 \mu \mathrm{mol} 5$-bromo-2'-deoxyuridine $\mathbf{1}^{-1}$ (Boehringer, Mannheim) at $37^{\circ} \mathrm{C}$ in a humid chamber for 45 min to detect BrdU incorporation. Cells were washed three times in PBS and fixed with $70 \%$ ethanol (in $50 \mathrm{mmol}$ glycine buffer $1^{-1}, \mathrm{pH} 2.0$ ) for $25 \mathrm{~min}$ at $-20^{\circ} \mathrm{C}$, and then the coverslips were washed three times in PBS and covered with $50 \mu \mathrm{l}$ of a mouse monoclonal anti-BrdU antibody (1:10 in $66 \mathrm{mmol}$ Tris-buffer $\mathrm{I}^{-1} \quad$ containing $0.66 \mathrm{mmol} \quad \mathrm{MgCl}_{2} \quad \mathrm{I}^{-1}$, $1 \mathrm{mmol} 2$-mercaptoethanol $\mathrm{l}^{-1}$ and nucleases for DNA denaturation; Boehringer). After incubation for $30 \mathrm{~min}$ at $37^{\circ} \mathrm{C}$ and washing in PBS, a FITC-conjugated sheep antimouse immunoglobulin (1:10 in PBS containing $1 \%(\mathrm{w} / \mathrm{v})$ BSA; Boehringer) was added and cells were incubated for another $30 \mathrm{~min}$ at $37^{\circ} \mathrm{C}$ before final washing in PBS. The cells stained for PCNA, as well as for BrdU, were covered with 50 $\mu l$ propidium iodide (1:250 in PBS; Sigma) and incubated for $5 \mathrm{~min}$ at room temperature and washed three times in PBS before mounting. Finally, the coverslips were mounted on glass slides in Vectashield (Vector Laboratories, Burlingame, CA) and sealed with nail varnish. Slides were viewed with a Zeiss Axiovert microscope fitted with a $\times 100$ oil immersion objective.

\section{Nuclear transfer and embryo culture}

The nuclear transfer procedure was that described by Zakhartchenko et al. (1995), with substantial modifications concerning the timing of fusion and activation of recipient oocytes. At $18-20 \mathrm{~h}$ after maturation, oocytes were denuded of cumulus cells and enucleated within $2 \mathrm{~h}$. A single cell suspension of starved or non-starved fibroblasts was prepared by trypsinization $10-15 \mathrm{~min}$ before nuclear transfer.

At $20-22 \mathrm{~h}$ after maturation, individual fibroblasts were transferred into the perivitelline space of enucleated oocytes, equilibrated for $5 \mathrm{~min}$ at $39^{\circ} \mathrm{C}$ in Zimmermann cell fusion medium (Robl et al., 1987), and transferred to a fusion chamber consisting of two electrodes $500 \mu \mathrm{m}$ apart, overlaid with fusion medium. The karyoplast-cytoplast complexes (KCCs) were exposed to a double electric pulse of $2.1 \mathrm{kV} \mathrm{cm}^{-1}$ for $10 \mu$ s to initiate their fusion (Zakhartchenko et al., 1995). KCCs were placed in Ham's F-12 medium (Sigma) supplemented with $10 \%(\mathrm{v} / \mathrm{v})$ fetal calf serum and maintained at $39^{\circ} \mathrm{C}$ in a humidified atmosphere of $5 \% \mathrm{CO}_{2}$ in air. Fusion rates were determined 30-60 min after the fusion pulse.

At $24 \mathrm{~h}$ after maturation, the fused KCCs were activated by a $5 \mathrm{~min}$ incubation in $7 \%(\mathrm{v} / \mathrm{v})$ ethanol followed by $5 \mathrm{~h}$ culture in $10 \mu \mathrm{g}$ cycloheximide $\mathrm{ml}^{-1}$ and $5 \mu \mathrm{g}$ cytochalasin B $\mathrm{ml}^{-1}$ (Presicce and Yang, 1994). KCCs were transferred into $100 \mu$ l drops of CR-1 medium (Rosenkrans and First, 1991) supplemented with $10 \%(\mathrm{v} / \mathrm{v})$ oestrous cow serum, which were covered by paraffin oil, and cultured for 7-8 days at $39^{\circ} \mathrm{C}$ in a humidified atmosphere of $5 \% \mathrm{CO}_{2}, 5 \% \mathrm{O}_{2}$ and $90 \%$ $\mathrm{N}_{2}$. The proportions of blastocysts and hatched blastocysts, respectively, were recorded on days 7 and 8 of in vitro culture. Nuclear transfer experiments with starved and non-starved fibroblasts were replicated six times.

Some day 5 fibroblast-derived nuclear transfer morulae were disaggregated and used for a second round of nuclear transfer (re-cloning). In these experiments, enucleated 
oocytes were activated $24 \mathrm{~h}$ after maturation as described above and then fused with embryonic cells at 31-32 h after maturation. Re-cloning experiments were replicated three times with donor embryos derived from both starved and non-starved fibroblasts.

Some day 8 blastocysts of excellent or good quality produced in the first round of nuclear transfer from starved fibroblasts were used for differential staining to count the numbers of cells in nuclear transfer embryos. Similar quality day 8 nuclear transfer blastocysts produced by the fusion of day 6 morula blastomeres with activated oocytes at 31-32 h after maturation served as controls. The inner cell mass (ICM) cells and trophectoderm (TE) cells were differentially stained with fluorochromes using the procedure described by Stojkovic et al. (1998).

\section{Embryo transfer}

Excellent or good quality embryos (classified in accordance with Lindner and Wright, 1983) that had been cultured in vitro for 7 days were transferred to synchronous recipients 7 days after standing oestrus which were treated by the injection of $2.0 \mathrm{ml}$ Estrumate (Mallinckrodt Vet. $\mathrm{GmbH}$, Burgwedel) to evaluate the viability of nuclear transfer blastocysts derived from fibroblast nuclei. The recipients were examined on day 30 after embryo transfer by ultrasonography for the presence of a conceptus, and by palpation per rectum at 42,60 and 90 days of gestation.

\section{DNA analysis}

DNA samples were compared using microsatellite analysis to determine whether the retrieved calves have the same genotype as the donor fibroblasts. The analysis of microsatellite loci was performed using the StockMarks ${ }^{\mathrm{TM}}$ Kit for Cattle Bovine Paternity PCR Typing (PE Applied Biosystems, Weiterstadt) which is based on nine microsatellite loci and uses four-dye fluorescent labelling. Fluorescence data collected by GeneScan software were exported directly to the Genotyper software for automated genotyping (PE Applied Biosystems).

\section{Statistical analysis}

Differences between experimental groups were verified using chi-squared analysis (fusion rates and development
Table 1. Immunofluorescence staining of non-starved or starved bovine fibroblasts

\begin{tabular}{|c|c|c|}
\hline Fibroblasts & $\begin{array}{l}\text { Positive cells for PCNA } \\
\qquad(\% \pm \mathrm{SD})\end{array}$ & $\begin{array}{l}\text { Positive cells for BrdU } \\
\qquad(\% \pm \mathrm{SD})\end{array}$ \\
\hline Non-starved & $214 / 845(25.3 \pm 1.3)^{a}$ & $204 / 888(22.9 \pm 2.7)^{a}$ \\
\hline Starved & $47 / 848(5.4 \pm 1.1)^{\mathrm{b}}$ & $34 / 846(3.9 \pm 0.8)^{\mathrm{b}}$ \\
\hline
\end{tabular}

BrdU, 5-bromo-2'-deoxyuridine; PCNA, proliferating cell nuclear antigen. ab Values within columns with different superscripts differ $(P<0.001)$

rates). Differences between the proportions of cells positively stained for PCNA and BrdU incorporation as well as ICM and total cell numbers were analysed by Mann-Whitney $U$ test. $P<0.05$ was considered significant.

\section{Results}

\section{Effects of serum starvation on the cell cycle of fetal} fibroblasts

Immunofluorescence detection of PCNA or BrdU showed that serum starvation significantly decreased the proportions of fibroblasts that were in S phase (5 and $4 \%$ of the starved fibroblasts versus 25 and $23 \%$ of non-starved fibroblasts, respectively, for PCNA and BrdU; $P<0.001$; Table 1).

\section{Effects of serum starvation on the development in vitro of reconstructed embryos}

Fusion rates obtained with starved fibroblasts tended to be higher than those obtained with non-starved cells (Table 2). Nuclear transfer embryos derived from starved fibroblasts cleaved at a significantly $(P<0.05)$ higher rate than those derived from non-starved fibroblasts. The nuclei of starved fibroblasts supported the development to blastocysts and hatched blastocysts significantly $(P<0.05)$ better than those of non-starved fibroblasts.

\section{Cell number analysis of day 8 nuclear transfer blastocysts}

Morphologically, day 8 nuclear transfer blastocysts derived from fibroblasts $(n=21)$ were similar to those obtained from embryonic cells $(n=17)$. There were no significant differences $(P>0.05)$ in the numbers of inner cell mass cells $(54.1 \pm 11.3$ and $50.9 \pm 17.5$ in fibroblast-derived

Table 2. Development in vitro of nuclear transfer embryos derived from non-starved or starved bovine fetal fibroblasts

\begin{tabular}{|c|c|c|c|c|c|}
\hline Fibroblast type & $\begin{array}{l}\text { Number of karyoplast- } \\
\text { cytoplast complexes }\end{array}$ & $\begin{array}{c}\text { Fused } \\
(\%)\end{array}$ & $\begin{array}{l}\text { Cleaved } \\
(\%)\end{array}$ & $\begin{array}{c}\text { Blastocyst* } \\
(\%)\end{array}$ & $\begin{array}{c}\text { Hatched } \\
\text { blastocyst* }(\%)\end{array}$ \\
\hline Non-starved & 242 & $174(72)^{a}$ & $115(66)^{\prime \prime}$ & $35(20)^{\mathrm{a}}$ & $24(14)^{\mathrm{a}}$ \\
\hline Starved & 254 & $205(81)^{\mathrm{a}}$ & $158(77)^{\mathrm{b}}$ & $80(39)^{\mathrm{b}}$ & $58(28)^{b}$ \\
\hline Total & 496 & $379(76)$ & $273(72)$ & $115(30)$ & $82(22)$ \\
\hline
\end{tabular}

*Percentages were calculated on the basis of the number of fused embryos.

ab Values within columns with different superscripts differ $(P<0.05)$. 
Table 3. Development in vitro of bovine embryos reconstructed with donor nuclei from fibroblast-derived nuclear transfer morulae

\begin{tabular}{lccccc}
\hline $\begin{array}{l}\text { Source of donor } \\
\text { morulae }\end{array}$ & $\begin{array}{c}\text { Number of karyoplast- } \\
\text { cytoplast complexes }\end{array}$ & $\begin{array}{c}\text { Fused } \\
(\%)\end{array}$ & $\begin{array}{c}\text { Cleaved } \\
(\%)\end{array}$ & $\begin{array}{c}\text { Blastocyst* } \\
(\%)\end{array}$ & $\begin{array}{c}\text { Hatched } \\
\text { blastocyst }^{*}(\%)\end{array}$ \\
\hline $\begin{array}{l}\text { Non-starved fibroblasts } \\
\text { Starved fibroblasts }\end{array}$ & 65 & $58(89)$ & $50(86)$ & $32(55)$ & $23(40)$ \\
Total & 103 & $91(88)$ & $73(80)$ & $47(52)$ & $36(40)$ \\
\hline
\end{tabular}

*Percentages were calculated on the basis of the number of fused embryos.

and embryonic cell-derived blastocysts, respectively) and total cells $(132.3 \pm 31.7$ and $152.9 \pm 37.5$ in fibroblast-derived and embryonic cell-derived blastocysts, respectively).

\section{Re-cloning of fibroblast-derived nuclear transfer embryos}

When nuclear transfer morulae derived from starved or non-starved fibroblasts were used for re-cloning (Table 3), the rates of fusion, cleavage, and development to blastocysts and hatched blastocysts were not affected by the source of donor nuclei. The proportions of blastocysts obtained with embryonic nuclei from fibroblast-derived nuclear transfer morulae were significantly higher than those obtained with the fibroblast cell nuclei used in the first round of nuclear transfer (Fig. 1; starved: 52 versus 39\%, $P<0.05$; non-starved: 55 versus $20 \%, P<0.001$ ). In addition, re-cloning increased the proportion of hatched blastocysts (Table 3 ).

\section{Development in vivo of fibroblast-derived nuclear transfer blastocysts}

After transfer of blastocysts derived from non-starved and starved fibroblasts, respectively, 33\% (1/3) and $78 \%(7 / 9)$ recipients were pregnant on day 30 as assessed by ultrasonography (Table 4). One recipient of a starved fibroblast-derived blastocyst was slaughtered on day 60 to evaluate the morphology of the fetus. This fetus did not show any obvious abnormalities. Another fetus derived from a starved fibroblast was aborted on day 78 of gestation. Pregnancy was confirmed on day 90 in $1 / 3(33 \%)$ and in $5 / 8$ $(63 \%)$ recipients that received blastocysts derived from nonstarved and starved fibroblasts, respectively. In the starvedfibroblasts group, abortion had to be induced between 5 and 6 months of gestation in two recipients owing to

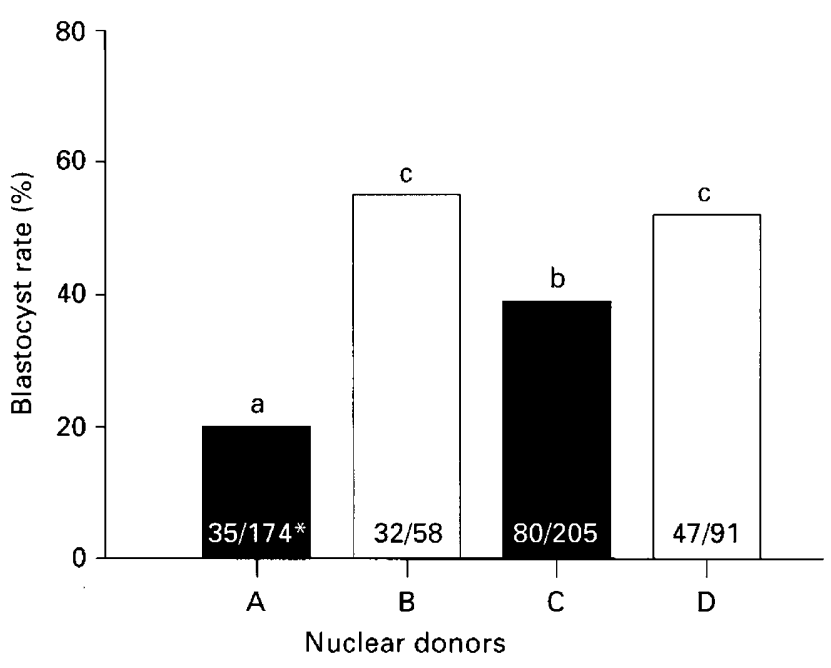

Fig. 1. Effect of first and second rounds of nuclear transfer on development in vitro of non-starved and starved fibroblast-derived embryos. A, non-starved fibroblasts; B, non-starved fibroblastderived morulae; $C$, starved fibroblasts: D, starved fibroblastderived morulae. abc Values with different superscripts differ (chi-squared, $P<0.05$ ). ${ }^{*}$ Blastocyts from fused karyoplast-cytoplast complexes.

hydroallantois. Each of these recipients carried one normal and one oversized fetus. DNA microsatellite analysis confirmed that all these clones originated from the fibroblast cell line (Table 5). One recipient aborted a starved fibroblastderived fetus at the eighth month of pregnancy and the second one, carrying the same type of fetus, was induced to abortion at the last month of pregnancy owing to hydroallantois. Two live male twin calves, derived from non-starved fibroblasts, were delivered by Caesarean section on day 281 of gestation. The birth weights of these calves

Table 4. Development in vivo of nuclear transfer bovine embryos derived from non-starved or starved fetal fibroblasts

\begin{tabular}{|c|c|c|c|c|c|c|c|c|c|c|c|}
\hline \multirow{2}{*}{$\begin{array}{l}\text { Fibroblast } \\
\text { type }\end{array}$} & \multirow{2}{*}{$\begin{array}{l}\text { Number of } \\
\text { transferred } \\
\text { blastocysts }\end{array}$} & \multirow{2}{*}{$\begin{array}{l}\text { Number of } \\
\text { recipients }\end{array}$} & \multicolumn{4}{|c|}{ Number pregnant on day (\%) } & \multicolumn{4}{|c|}{ Number of fetuses on day $(\%)^{*}$} & \multirow{2}{*}{$\begin{array}{l}\text { Number of } \\
\text { calves }(\%)^{*}\end{array}$} \\
\hline & & & 30 & 60 & 90 & 210 & 30 & 60 & 90 & 210 & \\
\hline Non-starved & 7 & 3 & $1 / 3(33)$ & $1 / 3(33)$ & $1 / 3(33)$ & $1 / 3(33)$ & $2(28)$ & $2(28)$ & $2(28)$ & $2(28)$ & $2(28)$ \\
\hline Starved & 16 & 9 & $7 / 9(78)$ & $6 / 8(75)^{* *}$ & $5 / 8(63)$ & $2 / 8(25)$ & $9(56)$ & $9(56)$ & $7(44)$ & $2(13)$ & 0 \\
\hline
\end{tabular}

* On the basis of the number of transferred blastocysts.

${ }^{* *}$ One recipient was slaughtered on day 60 . 
Table 5. Microsatellite analysis of nine loci using the StockMarks ${ }^{\mathrm{TM}} \mathrm{kit}^{\mathrm{t}}$

\begin{tabular}{|c|c|c|c|c|c|c|c|c|}
\hline Locus/allele & $\mathrm{BEF}$ & CC1-98 & RM1-98 & CCI324 & CCII324 & RM324 & $\mathrm{CCI} 325$ & RM325 \\
\hline TGLA57 1 & $93.36^{*}$ & 93.37 & 86.67 & 93.44 & 93.42 & 93.27 & 93.28 & 93.37 \\
\hline TGLA57 2 & 97.85 & 97.88 & 93.41 & 97.87 & 97.83 & 93.27 & 97.82 & 95.52 \\
\hline TGLA73 1 & 112.89 & 112.81 & 116.69 & 112.90 & 112.77 & 116.60 & 112.75 & 116.53 \\
\hline TGLA73 2 & 118.80 & 118.70 & 118.68 & 118.68 & 118.73 & 116.60 & 118.64 & 118.61 \\
\hline MGTG4B 1 & 131.95 & 131.99 & 132.02 & 131.87 & 131.77 & 131.88 & 131.85 & 131.72 \\
\hline MGTG4B 2 & 131.95 & 131.99 & 134.11 & 131.87 & 131.77 & 131.88 & 131.85 & 146.90 \\
\hline AGLA2931 & 228.11 & 228.30 & 220.02 & 227.99 & 227.90 & 224.01 & 227.92 & 227.69 \\
\hline AGLA293 2 & 228.11 & 228.30 & 224.06 & 227.99 & 227.90 & 227.90 & 227.92 & 238.48 \\
\hline TGLA48 1 & 74.01 & 74.14 & 72.06 & 74.10 & 74.10 & 71.93 & 74.00 & 71.81 \\
\hline TGLA48 2 & 74.01 & 74.14 & 72.06 & 74.10 & 74.10 & 71.93 & 74.00 & 73.90 \\
\hline TGLA122 1 & 138.31 & 138.21 & 146.79 & 138.30 & 138.19 & 138.31 & 138.19 & 146.77 \\
\hline TGLA122 2 & 146.84 & 146.78 & 146.79 & 146.81 & 146.81 & 150.89 & 146.81 & 146.77 \\
\hline TGLA263 1 & 116.21 & 116.37 & 118.68 & 116.18 & 116.12 & 105.81 & 116.12 & 105.78 \\
\hline TGLA263 2 & 118.37 & 118.49 & 118.68 & 118.27 & 118.30 & 118.35 & 118.20 & 118.17 \\
\hline TGLA53 1 & 151.01 & 151.12 & 157.58 & 150.89 & 151.02 & 159.50 & 150.89 & 159.62 \\
\hline TGLA532 & 167.86 & 167.96 & 165.95 & 167.75 & 167.82 & 159.50 & 167.73 & 165.73 \\
\hline TGLA126 1 & 112.25 & 112.08 & 112.21 & 112.15 & 112.13 & 110.31 & 112.10 & 110.25 \\
\hline TGLA1262 & 112.25 & 112.08 & 119.85 & 112.15 & 112.13 & 110.31 & 112.10 & 110.25 \\
\hline
\end{tabular}

BEF: fibroblast cell line; CC1-98, CCI324, CCII324, CCI325: retrieved cloned calves; RM1-98, RM324, RM325: recipient mothers.

Both alleles (1 and 2) from each locus are shown. Microsatellite loci TGLA227 and MGTG7 amplified poorly in all samples and were not considered for paternity testing. Numbers are fragment lengths in base pairs as calculated by computer-aided analysis using an internal lane molecular size standard provided with the StockMarks ${ }^{\top M}$ Cattle Bovine Paternity PCR Typing Kit (PE Applied Biosystems).

were 31 and $50 \mathrm{~kg}$. The larger calf died 3 days after birth owing to insufficient pulmonary function, while the other is apparently normal and healthy.

\section{Discussion}

The effects of serum starvation and re-cloning were studied to optimize the efficiency of nuclear transfer using cultured bovine fetal fibroblasts. The proportion of nuclear transfer blastocysts derived from fibroblast cell nuclei ranged from $20 \%$ (non-starved) to $39 \%$ (starved) and was in the same range as values obtained after fusion of blastomeres from day $5(19 \%)$ or day 6 morulae $(34 \%)$ with pre-activated aged (42-45 h after maturation) oocytes (Zakhartchenko et al., 1997). The advantages of using pre-activated versus nonactivated cytoplasts depend on the cell cycle stage of donor nuclei. If donor cells are in mitosis (Kwon and Kono, 1996; Liu et al., 1997) or in the G1 phase (Collas et al., 1992a; Cheong et al., 1993) of the cell cycle, nuclear transfer is most efficient with non-activated cytoplasts. However, transfer of nuclei in S or G2 phase to non-activated cytoplasts with high concentrations of maturation promoting factor leads to nuclear envelope breakdown (NEBD) and premature chromatin condensation (PCC), resulting in damaged chromatin or tetraploidy, respectively (Campbell et al., 1996 b). In contrast to embryonic cells which are mainly in $S$ phase (Barnes et al., 1993), fetal fibroblasts were most efficient in combination with non-activated cytoplasts (Wells et al., 1998). However, with pre-activated cytoplasts, nuclear transfer using fibroblasts or fibroblast-like muscle and skin cells was relatively inefficient (7-10\% development to blastocysts; Vignon et al., 1998).

It has been suggested that NEBD and PCC are essential for the reprogramming of gene expression (Collas et al., 1992b) and are important processes for the development of nuclear transfer embryos to term (Cheong et al., 1994), and it has been argued that prolongation of the period of exposure of the donor nucleus after loss of its nuclear envelope to cytoplasmic factors enhances the developmental potential of the reconstructed embryo (Szöllosi et al., 1988). In cattle, Wells et al. (1998) obtained a significantly higher proportion of blastocysts by fusion of fibroblasts with recipient cytoplasm $4-8 \mathrm{~h}$ before activation than when reconstructed embryos were activated and fused simultaneously (52 versus $25 \%$ ). These authors suggest that the increase in embryo development obtained is due to the facilitation of nuclear remodelling and reprogramming.

In the present study, the development of nuclear transfer embryos to the blastocyst stage was significantly improved when donor fibroblasts were serum starved. Immunofluorescence staining showed that the proportion of fibroblasts in $S$ phase of the cell cycle decreased significantly after serum starvation. Serum starvation has been shown to synchronize donor cells in G0 of the cell cycle (Wilmut et al., 1997). The chromatin of quiescent nuclei has been reported to undergo a number of modifications, including a reduction in transcription and chromatin condensation (Whitfield et al., 1985). Such modifications may change the chromatin structure in such a way as to make it more readily reprogrammed after nuclear transfer.

However, an acceptable rate of development to the blastocyst stage was also obtained without serum starvation of donor fibroblasts, indicating that this treatment is not necessary for nuclear reprogramming. Cibelli et al. (1998) have produced cloned transgenic calves from non-starved transfected fetal fibroblasts. On the basis of the fact that rapid cell divisions occur in early embryonic development and the 
assumption that this may be an indication of relatively undifferentiated cells, these authors selected mitotically active cells for nuclear transfer. However, the development to blastocysts $(12 \%)$ was relatively low in this study. Furthermore, the proportion of cells in $\mathrm{S}$ phase has been overestimated due to inappropriate fixation procedures (reviewed in Campbell, 1998).

In addition to effects of serum starvation the efficiency of re-cloning of fetal fibroblast-derived nuclear transfer morulae was evaluated. When embryonic cells were used as initial nuclear donors, live calves were obtained from third generation nuclear transfer embryos (Stice and Keefer, 1993; Takano et al., 1997). A study by Ectors $e t$ al. (1995) did not reveal differences in developmental potential between first and second generation clones, while Lewis et al. (1998) reported increased developmental rates after the third round of nuclear transfer. In amphibians, development has been enhanced by the transfer of donor nuclei into oocytes followed by re-cloning (Orr et al., 1986). Differentiated nuclei developed to advanced tadpoles when the nuclei were transferred back into enucleated eggs after the initial transfer into the oocytes; nuclei that were not transferred back to the egg had lower developmental potential. These findings and the results of the present study suggest that an additional round of nuclear transfer exposes the donor nucleus more extensively to conditioning factors in oocyte cytoplasm, increasing the developmental potential of second generation nuclear transfer embryos.

Studies on bovine nuclear transfer using blastomeres as donor nuclei have shown a high incidence of pregnancy loss and placental abnormalities. The greatest number of established pregnancies was lost between day 30 and day 90 of gestation (Willadsen et al., 1991). In the present study, from eight established pregnancies, only one was lost by abortion before day 90 . However, developmental abnormalities including fetal oversize and hydroallantois occurred around or after mid-gestation. Further studies are necessary to unravel the potential causes of these abnormalities which may be due to experimental manipulations of the early embryonic stages.

In conclusion, the present study demonstrates a positive effect of serum starvation on the efficiency of nuclear transfer using bovine fetal fibroblasts. The efficiency of nuclear transfer may be further increased by re-cloning.

The authors thank R. Achman for his support with microsatellite analysis and P. Stojkovic and R. Dunkl for technical assistance. They also thank J. Motlik for the critical reading of the manuscript. G. Durcova-Hills was supported by grant GZ 45.379/1-IV from Austrian Ministry of Science. This study was supported by the Bayerische Forschungsstiftung (grant 76/93) and by the Deutsche Forschungsgemeinschaft (WO 685/2-1).

\section{References}

Barnes FL, Collas P, Powell R, King W, Westhusin M and Shepherd D (1993) Influence of recipient's oocyte cell cycle stage on DNA synthesis, nuclear envelope breakdown, chromosome constitution, and development in nuclear transfer bovine embryos Molecular Reproduction and Development 36 33-41

Butler D (1998) French clone provides support for Dolly Nature 392113

Campbell KH (1998) Look on the bright side of cloning Nature Medicine 4 557-558
Campbell KH, McWhir J, Ritchie W and Wilmut I (1996a) Sheep cloned by nuclear transfer from a cultured cell line Nature 380 64-66

Campbell KH, Loi P, Otaegui PJ and Wilmut I (1996b) Cell cycle coordination in embryo cloning by nuclear transfer Reviews of Reproduction 1 $40-46$

Carvalcho RV, Delcampo MR, Palasz AT, Plante Y and Mapletof RJ (1996) Survival rates and sex ratio of bovine IVF embryos frozen at different developmental stages on day 7 Theriogenology 45 489-498

Cheong HT, Takahashi $\mathbf{Y}$ and Kanagawa H (1993) Birth of mice after transplantation of early cell cycle stage embryonic nuclei into enucleated oocytes Biology of Reproduction 48 958-963

Cheong HT, Takahashi Y and Kanagawa H (1994) Relations between nuclear remodelling and subsequent development of mouse embryonic nuclei transferred to enucleated oocytes Molecular Reproduction and Development 37 138-145

Cibelli JB, Stice SL, Golueke PJ, Kane JJ, Jerry J, Blackwell C, Ponce de Leon FAP and Robl JM (1998) Cloned transgenic calves produced from nonquiescent fetal fibroblast Science 280 1256-1258

Collas P, Balise JJ and Robl JM (1992a) Influence of cell cycle stage of donor nucleus on development of nuclear transplant rabbit embryos Biology of Reproduction 46 492-500

Collas P, Pinto-Correia C, Ponce de Leon FA and Robl JM (1992b) Effect of donor cell cycle stage on chromatin and spindle morphology in nuclear transplant rabbit embryos Biology of Reproduction 46 501-511

Ectors FJ, Delval A, Smith LC, Touati K, Remy B, Beckers J and Ectors F (1995) Viability of cloned bovine embryos after one or two cycles of nuclear transfer and in vitro culture Theriogenology 44 925-933

Itoh T, Aoyagi Y, Konishi H, Itakura T, Takedomi S, Yazawa S and Akane $K$ (1998) Nuclear transfer of bovine embryonic disc cells Theriogenology 49322 (Abstract)

Kwon OY and Kono T (1996) Production of sextuplet mice by transferring metaphase nuclei from four-cell embryos Journal of Reproduction and Fertility 1730 (Abstract)

Lewis IM, Peura TT, Lane MW, Vajta G and Trounson AO (1998) Pregnancies and live birth achieved vitrified multigenerational cattle nuclear transfer embryos Theriogenology 49323 (Abstract)

Lindner GM and Wright RWJ (1983) Bovine embryo morphology and evaluation Theriogenology $20407-416$

Liu L, Dai Y and Moor RM (1997) Nuclear transfer in sheep embryos: the effect of cell-cycle co-ordination between nucleus and cytoplasm and the use of in vitro matured oocytes Molecular Reproduction and Development 47 255-264

Orr NH, Di Berardino MA and McKinnel RG (1986) The genome of frog erythrocytes displays centuplicate replications Proceedings National Academy of Sciences USA 83 1369-1373

Presicce GA and Yang X (1994) Parthenogenetic development of bovine oocytes matured in vitro for $24 \mathrm{~h}$ and activated by ethanol and cycloheximide Molecular Reproduction and Development 38 380-385

Robl JM, Prather R, Barnes F, Eyestone W, Northey D, Gilligan B and First NL (1987) Nuclear transplantation in bovine embryos Journal of Animal Science 64 642-647

Rosenkrans CF and First NL (1991) Culture of bovine zygotes to the blastocyst stage: effects of amino acids and vitamins Theriogenology 35266 (Abstract)

Schnieke AE, Kind AJ, Ritchie WA, Mycock K, Scott AR, Ritchie M, Wilmut I, Colman A and Campbell KHS (1997) Human factor IX transgenic sheep produced by transfer of nuclei from transfected fetal fibroblasts Science $\mathbf{2 7 8}$ 2130-2133

Sims ML and First NL (1993) Production of calves by transfer of nuclei from cultured inner cell mass cells Proceedings National Academy of Sciences USA $906143-6147$

Stice SL and Keefer CL (1993) Multiple generational bovine embryo cloning Biology of Reproduction 48 715-719

Stice SL and Strelchenko N (1996) Domestic animal embryonic stem cells: progress toward germ-line contribution. In Biotechnology's Role in the Genetic Improvement of Farm Animals pp 189 Eds RH Miller, VG Pursel and HD Norman. Beltsville Symposia in Agricultural Research, Beltsville, MD

Stojkovic M, Büttner M, Zakhartchenko V, Brem G and Wolf E (1998) A reliable procedure for differential staining of in vitro produced bovine blastocysts: comparison of tissue culture medium 199 and Ménézo's B2 medium Animal Reproduction Science 50 1-9

Szöllosi D, Czolowska R, Szöllosi MS and Tarkowski AK (1988) Remodeling of mouse thymocyte nuclei depends on the time of their transfer into activated homologous oocytes Journal of Cell Science 91 603-613 
Takano H, Kozai C, Shimizu S, Kato Y and Tsunoda Y (1997) Cloning of bovine embryos by multiple nuclear transfer Theriogenology 47 1365-1373

Vignon X, Chesne P, LeBourhis D, Heyman Y and Renard JP (1998) Developmental potential of bovine embryos reconstructed with somatic nuclei cultured skin and muscle fetal celis Theriogenology 49392 (Abstract)

Wells DN, Misica PM, Day TAM and Tervit HR (1997) Production of cloned lambs from an established embryonic cell line: a comparison between in vivo and in vitro matured cytoplasts Biology of Reproduction 57 385-393

Wells DN, Misica PM, McMillan WH and Tervit HR (1998) Production of cloned bovine fetuses following nuclear transfer using cells from a fetal fibroblast cell line Theriogenology 49330 (Abstract)

Whitfield JF, Boynton AL, Rixon RH and Youdale T (1985) The control of cell proliferation by calcium, $\mathrm{Ca}^{2+}$-calmodulin, and cyclic AMP. In Control of Animal Cell Proliferation pp 331-365 Eds AL Boynton and HL Leffert. Academic Press, London
Willadsen SM, Janzen RE, McAlister RG, Shea BF, Hamilton G and McDermand D (1991) The viability of late morulae and blastocysts produced by nuclear transplantation in cattle Theriogenology 35 161-170

Wilmut I, Schnieke AE, McWhir J, Kind AJ and Campbell KHS (1997) Viable offspring derived from fetal and adult mammalian cells Nature 385 810-813

Wolf E, Zakhartchenko V and Brem G (1998) Nuclear transfer in mammals: recent developments and future perspectives journal of Biotechnology 65 99-110

Zakhartchenko V, Wolf E, Palma GA and Brem G (1995) Effect of donor embryo cell number and cell size on the efficiency of bovine embryo cloning Molecular Reproduction and Development 42 53-57

Zakhartchenko V, Stojkovic M, Brem G and Wolf E (1997) Karyoplast-cytoplast volume ratio in bovine nuclear transfer embryos: effect on the developmental potential Molecular Reproduction and Development 48 332-338 